option of smaller rural maternity units and units managed by midwives for low risk cases. ${ }^{14}$ The Expert Maternity Group has also proposed comprehensive antenatal and natal care by small teams of midwives for women with uncomplicated pregnancies. ${ }^{15} 16$

Caesarean Birth in Britain makes recommendations in line with these reports: more information on possible places of birth and packages of maternity care and smaller teams of midwives to look after identified caseloads of women throughout their pregnancy, birth, and the postnatal period. ${ }^{1}$ A more critical attitude by obstetricians may well help to avoid unnecessary interventions, though it may be just as important to have an organisation providing maternity care

1 Francome C, Savage W, Churchill H, Lewison H. Caesarean Birth in Britain. Middlesex University Press, 1993.

2 Savage $\mathrm{W}$, Francome C. British caesarean section rates: have we reached a plateau? $\mathrm{Br} \boldsymbol{\mathcal { O }}$ Obstet Gynaecol 1993;100:493-6.

3 National Institutes of Health. Cesarean Childbirth. Washington, DC: US Department of Health and Human Services, Public Health Service, US Government Printing Office, 1987. (Publication No 82-2067.)

4 Coltart TM, Davies JA, Katesmark M. Outcome of a second pregnancy after a previous caesarean section. Br f Obstet Gynaecol 1990;97:1 140-3.

5 Flamm BL, Newman LA, Thomas SJ, Fallon D, Yoshida MM. Vaginal birth after cesarean delivery: results of a 5-year multicenter collaborative study. Obstet Gymecol 1990;76:750-4.

6 Keirse MINC. Preterm delivery. In: Chalmers I, Enkin M, Keirse MINC. Effective care in pregnancy and childbirth. Oxford: Oxford University Press, 1989:1270-92.

7 Bodmer B, Benjamin A, McLean FH, Usher RH. Has use of cesarean section reduced the risk of delivery in breech presentation? Am $\mathcal{O}$ Obstet Gymecol 1986;154:44-50. for low risk women by midwives dedicated to protecting physiology.

A close cooperation between midwives, general practitioners, and obstetricians, with mutual respect for each other's special abilities, is a prerequisite for such a system to work.

PIETER E TREFFERS

Emeritus professor of obstetrics and gynaecology

MARIA PEL

Academic Medical Centre,

Consultant obstetrician

Department of Obstetrics and Gynaecology,

$1105 \mathrm{AZ}$ Amsterdam,

The Netherlands

8 Neilson JP. Cardiotocography during labour. $B M \Im$ 1993;306:347-8.

9 Freeman R. Fetal monitoring-a disappointing story. N Engl F Med 1990;3:624-6.

10 Grant A. Monitoring the fetus during labour. In: Chalmers I, Enkin M, Keirse MJNC eds. Effective care in pregnancy and childbirth. Oxford: Oxford University Press, 1989: 846-82.

11 Van Alten D, Eskes $M$, Treffers PE. Midwifery in the Netherlands. The Wormerveer study: selection, mode of delivery, perinatal mortality and infant morbidity. $\mathrm{Br} \mathcal{O}$ Obstet Gynaecol 1989;96:656-62.

12 Treffers PE, Eskes $M$, Kleiverda G, Van Alten D. Home births and minimal medical interventions. IAMA 1990;264:2203-8.

13 SIG Zorginformatie. faarboek verloskunde 1991. Utrecht: SIG, 1992.

14 Select Committee on Health. Second report. Maternity services. London: HMSO, 1992

15 Expert Maternity Group. Changing childbirth. London: HMSO, 1993.

16 Lilford R. Midwives to manage uncomplicated childbirth. BMF 1993;307:339-40.

\title{
Can we afford the welfare state?
}

\section{We can't afford not to have it}

Several recent articles in the $B M \Im$ have drawn attention to an apparent fiscal crisis in welfare states throughout Europe. In the Netherlands "the cabinet is determined to push ahead with the harshest cuts in the country's welfare system since the second world war." In France the government is to reduce the reimbursement that patients can claim for medical treatment and drugs, while raising the level of social security contributions. ${ }^{23}$ In Germany sickness pay is to be restricted, and cuts in other benefits are being mooted. ${ }^{4}$

Britain is no exception to this atmosphere of crisis. Dire warnings issue almost daily from cabinet ministers about the size and growth of the public deficit and the need to rein it back, preferably by cutting or eliminating key areas of spending on welfare. Peter Lilley, secretary of state for social security, has even produced a public document arguing that his department spends too much. ${ }^{5}$ Although few people, in or out of government, argue that the NHS needs cutting back, the government's latest expenditure plans suggest that the growth in NHS spending is to be sharply reduced, almost certainly below that necessary to keep pace with the growth in demand. ${ }^{6}$

But the apparent universality of this "crisis" is misleading. Many of the problems in continental Europe are specific to the country concerned. Germany is struggling with the costs of reunification. The Dutch have a particular problem with their equivalent of invalidity benefit, now being claimed by one sixth of their working population. France is suffering from massive unemployment generated by the "franc fort" policy. And all these countries are moving into recession.

So does Britain, too, have a welfare crisis? It is pulling out of recession, so that is less of a problem, but there are two other worries. One is apparently excessive spending on welfare in the short term, which is contributing to large deficits in the public sector ( $£ 50$ billion is estimated for the current fiscal year). The second is much longer term: ever increasing demands being placed on the welfare system by demographic and economic factors, such as the increase in single parents and - of more interest from a health perspective - the aging of the population.

The first point to note about the short term deficit is that, in so far as there is a problem, it is partly self induced. In the two years preceding the election the government increased spending by nearly $£ 40$ billion; for the NHS alone, resources increased by $12 \%$ in real terms ${ }^{6}$ (which probably goes a long way to explain the recent increases in activity rates in the NHS that have instead been attributed to the reforms).

Secondly, and more importantly, it is far from clear that spending on welfare is out of control. It is true that, in the three years up to 1992-3, the share of the gross domestic product taken up by public expenditure on health, personal social services, education, housing, and social security rose from $21.4 \%$ to $26.4 \%$. But this was partly due to the fall in the gross domestic product induced by the recession. Moreover, even the figure for 1992-3 is not excessive in historical terms. Since 1973, expenditure on welfare has fluctuated but has always remained between $22 \%$ and $26 \%$ of the gross domestic product. ${ }^{2}$

The long term problem is also exaggerated, particularly so far as aging is concerned. The numbers of elderly people in Britain will rise in the 20 years from 1991 to 2011 by less than half the increase that has already happened since 1971. The numbers rise more sharply after 2011 (particularly for those over 75), but, even by 2041 , four fifths of the population will still be aged below 65 . The estimated age dependency ratio (the number of people aged over 65 for every 100 aged 15-64) shows no great change until 2020, remaining at around 25; by 2040 it will have increased to 33.1 , but even then it will be well below that faced by other advanced countries, including 
France (38.2), Japan (37.8), and Germany before unification $(48 \cdot 2){ }^{8}$

Given these figures, it is unsurprising that the implications of an aging population for spending on welfare are not dramatic. It has been estimated that if Britain spent the same as it does now on welfare for each person of a given age, but had the age structure that will exist in 2041, the total spending on welfare would rise by just over $11 \%$, equivalent to about $2.5 \%$ of the gross domestic product. ${ }^{9}$ Another estimate confined to health and social services concludes that aging will add only $10 \%$ to per capita spending on these services by 2026. ${ }^{10}$

Moreover, the assumption that we shall continue to spend the same amount per person on the care and support of elderly people as we do now may be unjustified. This is particularly true with respect to health care. It is a matter of controversy whether elderly people at any given age are getting more or less healthy. ${ }^{11}$ But an increased awareness of the different cost effectiveness of treatment for people at different ages, coupled with pressures to allow people to "die with dignity," may lead to a shift of spending towards younger age groups. ${ }^{12}$

In fact, it could be argued that the real British crisis is quite the reverse of that commonly portrayed. A social phenomenon whose importance is difficult to exaggerate is the growth in inequality and poverty over the past decade. The personal disposable income of the average household after housing costs rose by $35 \%$ between 1979 and 1990-1; but that of the bottom $10 \%$ of the population fell by $14 \%$, and their share of the national income was halved. The proportion of people living in households with an income below half the average income in 1979 was $9 \%$; by $1990-1$ it had increased to $24 \% .{ }^{13}$ Without the welfare state the situation would be far worse. Welfare services are arguably the only bulwark against increasing poverty and ill health, social misery, and perhaps social instability. The question is not whether we can afford to have a properly funded welfare state; it is whether we can afford not to have one.

JULIAN LE GRAND Professorial fellow

King's Fund Institute,

London W2 4HT

1 Daruvalla A. Dutch welfare state cut by government. BMf 1993;307:152.

2 Dorozynski A. France's health service will cost more. $B M \Im$ 1993;306:1362.

3 Dorozynski A. France struggles to save Fr30bn. $B M Y$ 1993;307:86.

4 Karcher H. German workers fight loss of sickness pay to fund reforms. $B M F$ 1993;307:87.

5 Department of Social Security. The growth of social security. London: HMSO, 1993.

6 HM Treasury. The government's expenditure plans 1993-4 to 1995-6: Department of Health. London: HMSO, 1993. (Cm 2212.)

7 Hills J, Glennerster H, Le Grand J. Investigating welfare. London: London School of Economics, 1992. (Welfare State Programme discussion paper 92.)

1992. (Welfare State Programme discussion paper 92.)
Willetts D. The age of entitlement. London: Social Market Foundation, 1993.

8 Willetts D. The age of entitlement. London: Social Market Foundation, 1993.

9 Hills J. The future of welfare. York: Joseph Rowntree Foundation (in press).

10 Ermisch J. Fewer babies, longer lives. York: Joseph Rowntree Foundation, 1990. Robine JM, Blancher M, Dard JE. Health expectancy. London: HMSO, 1992. (OPCS studies on
medical and population subjects No 59.)

12 National Confidential Enquiry into Perioperative Deaths. Report of the national confidential enquiry into perioperative deaths 1991/2. London: NCEPOD, 1993.

13 Department of Social Security. Households below average income: a statistical analysis 1979-1990/1. London: HMSO, 1993.

\section{Atopy and its inheritance}

\section{Genetics is building a bridge between the immediate and delayed components of atopy}

It took a philologist to invent the word "atopy." Coca and Cooke launched it in 1923, but they had been supplied with the word, custom built, by Professor Perry of Colombia University. Since then atopy has more than lived up to its linguistic derivation as a "strange" disease: it has been slippery to handle, and establishing its mode of inheritance has sometimes seemed almost impossible. Nevertheless, a strong genetic component was obvious from the start. But so too was a contribution from the environment, creating an awkward tangle that has taken $\mathbf{7 0}$ years and the full might of the new genetics to unravel even to the present limited extent.

Atopy is a state in which an exuberant production of IgE occurs as a response to common environmental allergens, and atopic subjects may or may not develop one or more of the atopic diseases such as asthma, hay fever, and eczema. Investigators into the genetics of atopy therefore have two options: to look at IgE concentrations or to look for the atopic diseases themselves; and, of course, the two do not always correspond. Up to a third of those with undoubted atopic eczema, for example, have normal IgE concentrations.

In 1988 a multidisciplinary group in Oxford interested in respiratory allergy defined atopy on the basis not of clinical disease but of positive response to a prick test, a positive specific IgE titre, a high total concentration of IgE, or any combination of these. ${ }^{2}$ It proposed an autosomal dominant mode of inheritance and mapped a gene important in atopy to chromosome $11 \mathrm{q} 13 .{ }^{3}$ Inheritance via this locus was found to occur only through the female line. ${ }^{4}$ Atopy can, of course, be inherited paternally, and the authors thought that the proportion attributable to the locus on chromosome 11 was only about $60 \%$.

Several other groups have since failed to confirm the linkage in the families of either those with atopic eczema ${ }^{5}$ or those with respiratory allergy ${ }^{6.8}$ though the reasons for this are still not clear. ${ }^{10}$ Atopy is a complex condition: genetic heterogeneity and differences in definition, selection, and race may all have played some part.

Nevertheless, such contradictions are familiar to those who followed the earlier wave of clinically based inheritance studies. Atopic eczema, for example, with a reported concordance rate of 0.86 in monozygotic and 0.21 in dizygotic twins, ${ }^{11}$ has in its time been said to follow autosomal dominant, recessive, and polygenic modes of inheritance. This confusion remains, but recent studies, using more precise clinical definitions, have shown two interesting phenomena.

Firstly, atopic diseases tend to run true to type within each family: in some families most of the affected members will have eczema while in others asthma or hay fever will predominate. ${ }^{12} 13$ This constancy has still to be explained. Secondly, some studies confirm that atopic diseases, whether respiratory or eczematous, ${ }^{14}{ }^{15}$ are inherited more often from the mother than from the father, and this, of course, echoes the findings of the Oxford group and the locus on chromosome $11 \mathrm{q} 13$.

The Oxford group have now put forward a candidate gene which looks all the more plausible because of the group's IgE based definition of atopy. ${ }^{16}$ The high affinity receptor for IgE is composed of $\alpha, \beta$, and $\chi$ subunits. The $\beta$ subunit gene lies on chromosome $11 \mathrm{q} 13$ and is closely linked to the suspected gene for atopy. The high affinity IgE receptor is found both on mast cells, which are important in immediate hypersensitivity, and on Langerhans cells, which are important as antigen presenting cells in the skin. The Langerhans cells are the only 